\title{
Single-Channel Properties of Four Calcium Channel Types in Rat Motoneurons
}

\author{
Masashi Umemiya and Albert J. Berger \\ Department of Physiology and Biophysics, University of Washington School of Medicine, Seattle, Washington 98195
}

\begin{abstract}
Previous studies have demonstrated multiple components of whole-cell calcium currents in hypoglossal motoneurons (HMs); HMs possess a low-voltage-activated (LVA) current and three types of high-voltage-activated (HVA) calcium currents based on sensitivity to $\omega$-Aga IVA, $\omega$-Conotoxin GVIA ( $\omega$-CgTx) and dihydropyridine analogs (DHPs). In the present study, we recorded single-calcium channel activities from HMs using a cell-attached patch-clamp method and found four types of channels that could be dlscriminated based on kinetics, voltage dependency, DHP sensitivity, and single-channel conductances. The average single-channel conductances with $110 \mathrm{~mm}$ barium as a charge carrier were 7, 14, 20, and 28 pS. T-type channels had a single-channel conductance of $7 \mathrm{pS}$, activated at the most negative potentials for the calcium channels and inactivated during depolarization. L-type channels (DHP-sensitive channels) did not inactivate during depolarization and had a 28-ps single-channel conductance. Based on kinetics and sensitivity to holding potential, it is likely that the channels with conductances of $14 \mathrm{pS}$ and $20 \mathrm{pS}$ represent $\mathrm{N}$-type and $\mathrm{P}$-type channels, respectively. The $\mathrm{N}$-type channel (14 pS) was sensitive to holding potential, showed modal gating, and inactivated during maintained depolarizations, whereas the P-type channel (20 pS) was rather insensitive to holding potential and did not inactivate during depolarization.
\end{abstract}

[Key words: hypoglossal motoneuron, Bay $K 8644$, nifedipine, T-type calcium channel, $N$-type calcium channel, L-type calcium channel, P-type calcium channel]

Evidence from electrophysiological, pharmacological, and molecular studies indicates that neurons in the CNS express multiple types of voltage-activated calcium channels (Bean, 1989; Tsien et al., 1991; Llinas et al., 1992; Mintz et al., 1992; Snutch and Reiner, 1992; Viana et al., 1993; Umemiya and Berger, 1994). Calcium influx through these calcium channels influences many aspects of neuronal function, including excitability, transmitter release, gene expression, etc. It is possible that each type of calcium channel has a specific role in cellular function. Thus, it is important to determine the characteristics and behavior of single calcium channels in different neurons.

\footnotetext{
Received Mar. 17, 1994; revised Sept. 16, 1994; accepted Sept. 20, 1994.

We thank Dr. Douglas Bayliss for comments on the manuscript. This research was supported by Javits Neuroscience Investigator Award NS-14857 and HL49657 from the National Institutes of Health to A.J.B.

Correspondence should be addressed to Masashi Umemiya, Department of Physiology and Biophysics, SJ-40, University of Washington School of Medicine, Seattle, WA 98195

Copyright (C) 1995 Society for Neuroscience $0270-6474 / 95 / 152218-07 \$ 05.00 / 0$
}

Early studies in various neuronal tissues identified three types of calcium channels, $T$-, $\mathrm{N}$-, and $\mathrm{L}$-type calcium channels, that were identified by distinctive single-channel properties (Fox et al., 1987; Plummer et al., 1989; Artalejo et al., 1991; Mogul and Fox, 1991). A fourth type of calcium channel, the P-type calcium channel, was described in cerebellar Purkinje cells, and this type of channel contributes to the majority of voltage-activated calcium current in Purkinje cells (Llinas et al., 1992). The P-type channel in Purkinje cells is sensitive to $\omega$-Aga IVA, relatively insensitive to holding potential, and does not inactivate during depolarization (Regan, 1991; Mintz et al., 1992). At the single-channel level, P-type channels in Purkinje cells have multiple subconductance levels within the range of conductances of other high-voltage-activated (HVA) calcium channels (Usowicz et al., 1992). On the other hand, little is known about the singlechannel properties of P-type channels in other neurons. Although whole-cell calcium current recordings in hippocampal neurons have rcvcaled three components of IIVA calcium current, including the P-type channel (Mogul and Fox, 1991; Mintz et al., 1992), only L-type and N-type calcium channels were identified at the single-channel level (Mogul and Fox, 1991; O'Dell and Alger, 1991). It is possible that the density of P-type channels was too low to detect in cell-attached recordings from somata of hippocampal neurons.

To date there are no published reports in which single-channel properties of calcium channels in motoneurons have been characterized. Hypoglossal motoneurons (HMs) in newborn rats have both low-voltage-activated (LVA) and HVA calcium currents (Viana et al., 1993). On the basis of sensitivity to $\omega$-Aga IVA, P-type channels are responsible for approximately half of HVA calcium current (Umemiya and Berger, 1994). HMs also have smaller components of HVA current that are sensitive to $\omega$-CgTx (N-type) (35\%) and DHPs (L-type) (10\%). As these neurons have at least four components of calcium current, it may be possible to identify in HMs four types of calcium channels showing distinct single-channel properties. To characterize single-channel behavior of calcium channels in HMs, we recorded single-channel activities of calcium channels in an on-cell configuration. In the present study, we found four types of calcium channels based on kinetics, voltage dependency, DHP sensitivity, and single-channel conductance.

\section{Materials and Methods}

Preparation. Procedures for preparation of the thin slices were essentially identical to those described previously (Edwards et al., 1989; Takahashi, 1992; Viana et al., 1993; Umemiya and Berger, 1994). Briefly, Sprague-Dawley rats ( 2 to $6 \mathrm{~d}$ old) were anesthetized by hypothermia and rapidly decapitated. The brainstem was isolated and cut in 120 to $130 \mu \mathrm{m}$ transverse sections. The slices were incubated at $37^{\circ} \mathrm{C}$ for at least $1 \mathrm{hr}$ and then maintained at room temperature $\left(23-25^{\circ} \mathrm{C}\right)$. 
A
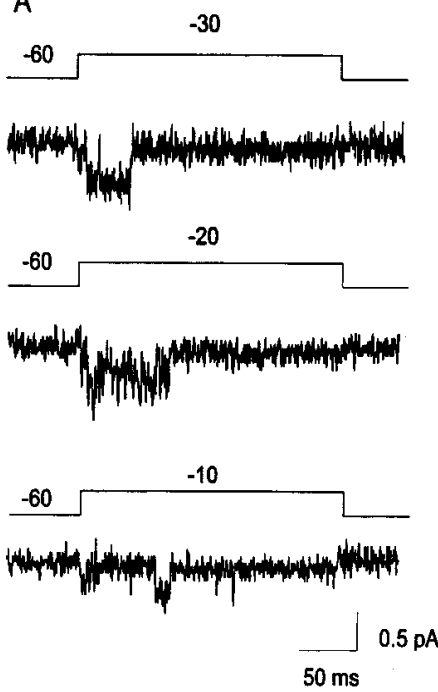

B

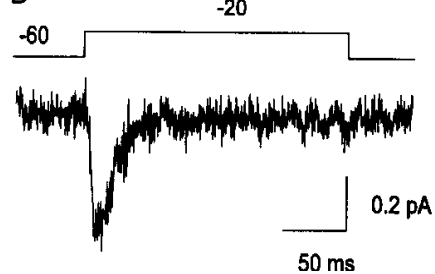

C

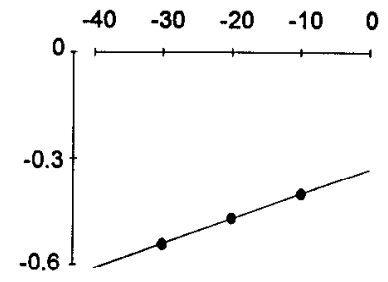

Figure 1. The $7 \mathrm{pS}$ calcium channel. $A$. Channel activities at different test potentials are shown. The channel was activated with $200 \mathrm{msec}$ depolarizing steps every 4 sec. This patch had at least three T-type channels and one L-type channel, but the L-type channel was rarely activated at potentials negative to $0 \mathrm{mV}$ (see Fig. $7 B$ ). To record activity from a single channel, the membrane potential was held at -60 $\mathrm{mV}$ to partially inactivate the T-type channels. $B$, Ensemble average of this channel at $-20 \mathrm{mV}$ test potential derived from 43 sweeps. The time constant of inactivation during depolarization was $20 \mathrm{msec}$. $C$, Current-voltage relationship of this channel between -30 and $-10 \mathrm{mV}$ gave a single-channel conductance of $7 \mathrm{pS}$.

Recording. Brainstem slices were viewed with Nomarski optics and HMs were identified visually by their location within the hypoglossal nucleus and by their size and shape. The surface of an identified HM was cleaned with a saline jet stream. Patch electrodes were pulled from glass capillaries (LC-16, Dagan) to a DC resistance of 6 to $10 \mathrm{M} \Omega$. In most experiments we used high-resistance electrodes $(\sim 10 \mathrm{M} \Omega)$ to limit the number of channels in a patch. Patch-clamp recordings were made at room temperature with an EPC-7 amplifier (List, Darmstadt, Germany). Seal resistance was usually more than $10 \mathrm{G} \Omega$. Stable recordings were maintained in patches for up to $45 \mathrm{~min}$, but stability was compro-
A

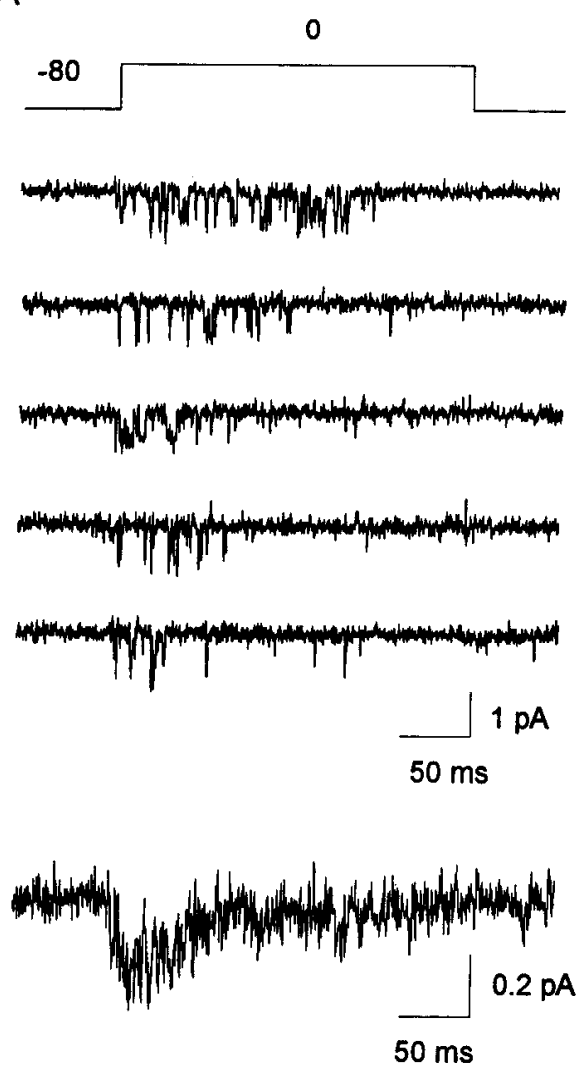

B
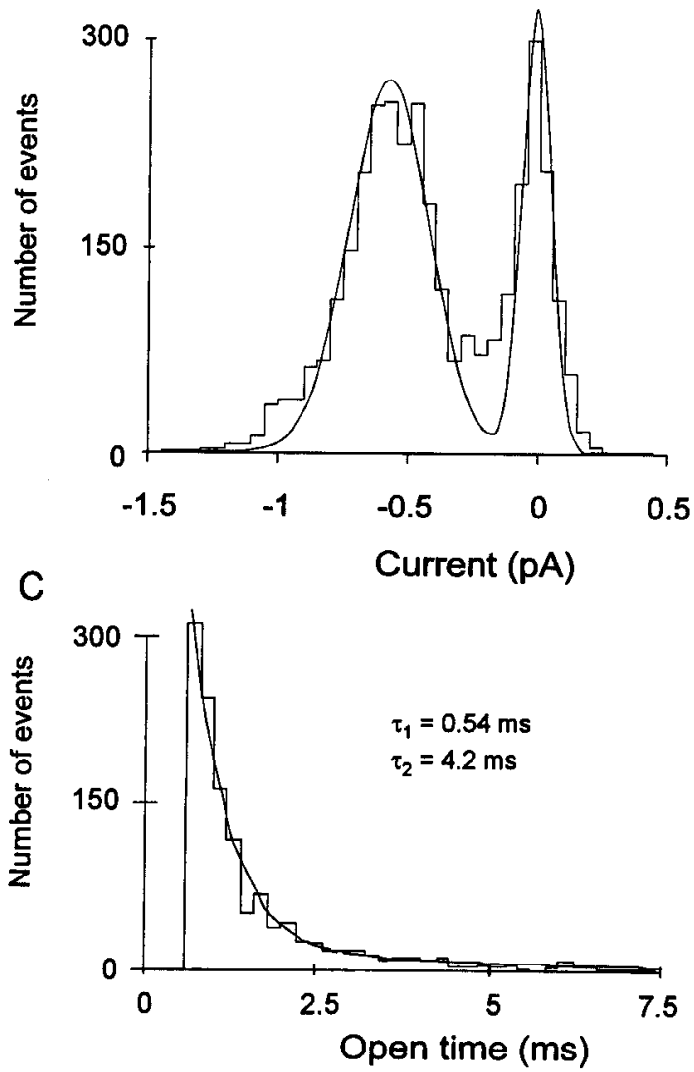

Figure 2. The $14 \mathrm{pS}$ channel. A, Sample records of the $14 \mathrm{pS}$ channel are shown. The holding potential was $-80 \mathrm{mV}$ and the channel was activated with $200 \mathrm{msec}$ depolarizing steps to $0 \mathrm{mV}$ every $4 \mathrm{sec}$. As almost no channel activity was observed from a holding potential of $-40 \mathrm{mV}$ (see Fig. 3), the channels in this patch did not have other types of HVA calcium channels. Bottom trace shows the ensemble average of channel activity derived from 33 sweeps. The time constant of the inactivation during depolarization was 58 msec. $B$, Amplitude histogram of this channel at $0 \mathrm{mV}$ test potential from a holding potential of $-80 \mathrm{mV}$. The distribution was fitted to the sum of two Gaussian functions. The open level is

$0.59 \mathrm{pA}$. Single-channel conductance of this channel is $14.4 \mathrm{pS}$ between -20 and $20 \mathrm{mV}$ (see Fig. $7 A$ ). $C$, Open time distribution of this channel at $0 \mathrm{mV}$ from a holding potential of $-80 \mathrm{mV}$. Open time distribution was fitted to the sum of two exponential functions with fractional contributions of 0.84 and 0.16 for $\tau_{1}$ and $\tau_{2}$, respectively, and each time constant is shown. 

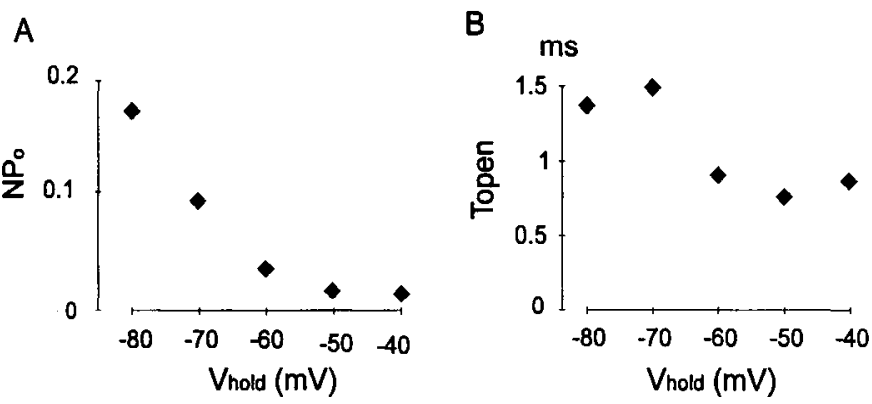

C

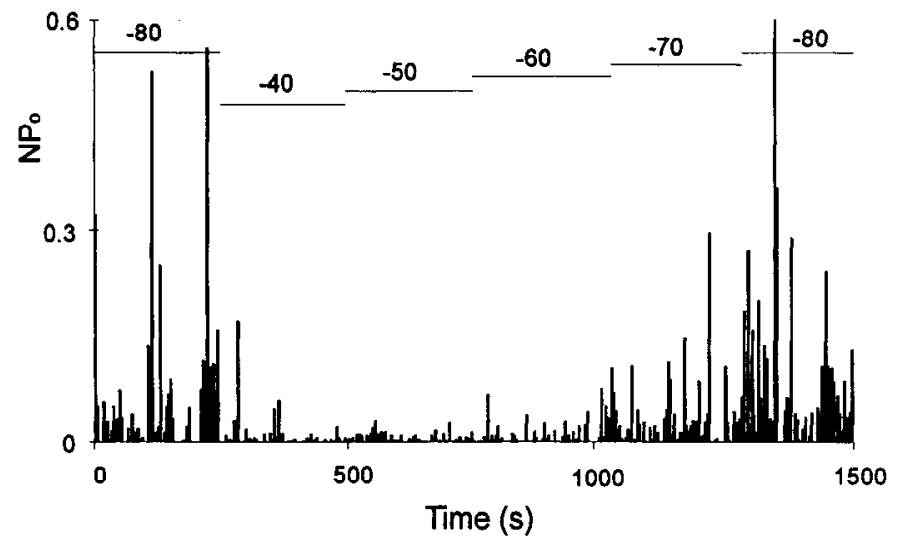

Figure 3. Steady-state inactivation of $14 \mathrm{pS}$ channel. The records were from the same patch shown in Figure 2. The relationships between holding potential and open probability $(A)$ and mean open time $(B)$ are shown. The calcium channel was activated by depolarizing steps to 0 $\mathrm{mV}$ for $200 \mathrm{msec}$ every $4 \mathrm{sec}$. The ordinate in $A$ is the open probability $(N P o)$ averaged from 64 sweeps of each holding potential. The ordinate in $B$ is mean open time for all openings from each holding potential. $C$, Channel activity $(N P o)$ of each sweep is plotted against recording time. Numbers in this figure indicate holding potentials during each period.

mised when patches were held at potentials more negative than -90 $\mathrm{mV}$. Currents elicited by depolarizing pulses, applied every $4 \mathrm{sec}$, were filtered at $1 \mathrm{kHz}$ with a four-pole, low-pass Bessel filter (Cornerstone, Dagan) and digitized at $5 \mathrm{kHz}$ or $10 \mathrm{kHz}$ using the pCLAMP system (Axon Instruments).

Data analysis. Linear leak currents and capacitive currents were subtracted digitally using the average of sweeps containing no channel activity. Events were detected using a criterion based on a $50 \%$ crossing method between open and closed levels. A transition between levels was accepted if the level changed for two or more sample data points $(>0.3 \mathrm{msec})$. Open probability ( $\mathrm{NPo}$ ) was calculated from the sum of open times for each sweep divided by sweep duration. For exponential fitting of open time distributions, we used the pCLAMP system, with a nonlinear least-squares curve-fitting method. Current anplitudes for the smallest calcium channels, $7 \mathrm{pS}$, were determined using manual onscreen cursors because of their low signal-to-noise ratios. For largeconductance calcium channels, 14,20 , and $28 \mathrm{pS}$, amplitude histograms were constructed from current amplitudes measured during $1 \mathrm{msec}$ periods prior to and during channel openings to reduce event numbers of the baseline amplitude (Artalejo et al., 1991). For these channels, the opening events were marked manually. Amplitude histograms were fitted to Gaussian distributions by the SigmaPlot software (Jandel) using the Levenberg-Marquardt algorithm with a convergence criterion of 2.5 $\times 10^{-7}$. In cases where a discrepancy between the data and fitted open level appeared significant, we fitted the baseline and open level separately with individual Gaussian distributions. We used Excel (Microsoft) and SigmaPlot for linear regression of the slope conductance and to fit decays of the ensemble current averages to exponential functions and activation curves to Boltzman functions.
Solutions. The ionic composition of the solution used for preparation of slices was (in mM) NaCl, 130; $\mathrm{NaHCO}_{3}, 26 ; \mathrm{NaHPO}_{4}, 1.25 ; \mathrm{KCl}, 3$; glucose, $10 ; \mathrm{CaCl}_{2}, 1 ; \mathrm{MgCl}_{2}, 5$. The solution used to maintain slices was similar in composition but $\mathrm{CaCl}_{2}$ was raised to $2 \mathrm{~mm}, \mathrm{MgCl}_{2}$ reduced to $2 \mathrm{mM}$, and lactic acid $(4 \mathrm{~mm})$ was added. The solutions were bubbled with $95 \% \mathrm{O}_{2}$ and $5 \% \mathrm{CO}_{2}$. During recording, membrane potential was nullified by bathing in an external solution containing $\mathrm{K}$-aspartate, 130; HEPES, 10; EGTA, 10; $\mathrm{MgCl}_{2}$, 5; glucose, $10(\mathrm{pH}=7.3$, adjusted by $\mathrm{KOH}$ ) and the pipette solution contained $\mathrm{BaCl}_{2}, 110$; HEPES, $10(\mathrm{pH}=7.3$, adjusted by TEAOH)

Drugs. S(-)-Bay K 8644 and nifedipine (Research Biochemicals, Inc.) were dissolved in DMSO and stored at $-20^{\circ} \mathrm{C}$. The final concentration of DMSO was $0.01 \%$. The same concentration of DMSO alone had no effect on calcium channels.

\section{Results}

Single-channel recordings of voltage-activated calcium channels were made from cell-attached patches in HMs using the thinslice preparation of the brainstem. The membrane potential was nullified using potassium aspartate $(130 \mathrm{~mm})$ in the external solution, and barium (110 mM) was used as a charge carrier. Thirty of 79 patches showed channel activities $(\sim 38 \%)$. As described below, these were discriminated into four classes by their singlechannel conductance, kinetics, voltage dependency, and DHP sensitivity. Of these, the most predominant type was the $28 \mathrm{pS}$ channel ( $n=13$ ), and the numbers of each channel type were, 10,8 , and 5 , for the $20 \mathrm{pS}, 7 \mathrm{pS}$, and $14 \mathrm{pS}$ channels, respectively.

\section{7-pS Calcium channels}

The smallest channels had a single-channel conductance of 7.4 $\pm 0.2 \mathrm{pS}$ (mean $\pm \mathrm{SE}$, range $=7.0$ to $8.0 \mathrm{pS}, n=8$ ). Figure $1 \mathrm{~A}$ shows sample activities of this channel at three test potentials. This channel showed activation at $-30 \mathrm{mV}$, the most negative activation potential for any of the calcium channel types in HMs. The ensemble average at a test potential of $-20 \mathrm{mV}$ shows complete inactivation during depolarizations (Fig. $1 B$ ). These channels appeared in clusters, since more than one channel was present in many of the patches. It was difficult to analyze this type of channel in detail because of its small conductance and the limited resolution of our recordings. Nevertheless, these characteristics are similar to those of T-type channels recorded in peripheral and CNS neurons (Fox et al., 1987; Mogul and Fox, 1991; O'Dell and Alger, 1991). Further, we showed previously that HMs have LVA calcium currents (Viana et al., 1993; Umemiya and Berger, 1994).

\section{4-pS Calcium channels}

A second channel type, with a single-channel conductance of 14 $\mathrm{pS}$, is shown in Figure $2 A$. The mean current amplitude of these channels was $-0.73 \pm 0.06 \mathrm{pA}(n=4)$ at a test potential of 0 $\mathrm{mV}$ (Fig. $2 B$ ) and the mean slope conductance was $14.1 \pm 0.3$ $\mathrm{pS}$ (range $=13.0$ to $14.6 \mathrm{pS}, n=5$ ) (see Fig. $7 A$ ). Similar to the $7 \mathrm{pS}$ channel, the ensemble average of this channel showed inactivation during depolarization, but the inactivation was slower than that of the $7 \mathrm{pS}$ channel (compare Figs. $1 B, 2 A$ ). The open time distribution at $0 \mathrm{mV}$ was fitted to a sum of two exponential functions with fast and slow time constants of 0.54 msec and $4.2 \mathrm{msec}$, respectively (Fig. $2 C$ ).

This channel was also sensitive to holding potential (Fig. 3). Very few openings were observed when stepping to $0 \mathrm{mV}$ from holding potentials positive to $-60 \mathrm{mV}$; frequency of openings increased as holding potential was more negative than $-60 \mathrm{mV}$ (Fig. $3 A, C$ ). All the $14 \mathrm{pS}$ channels tested showed similar volt- 
A

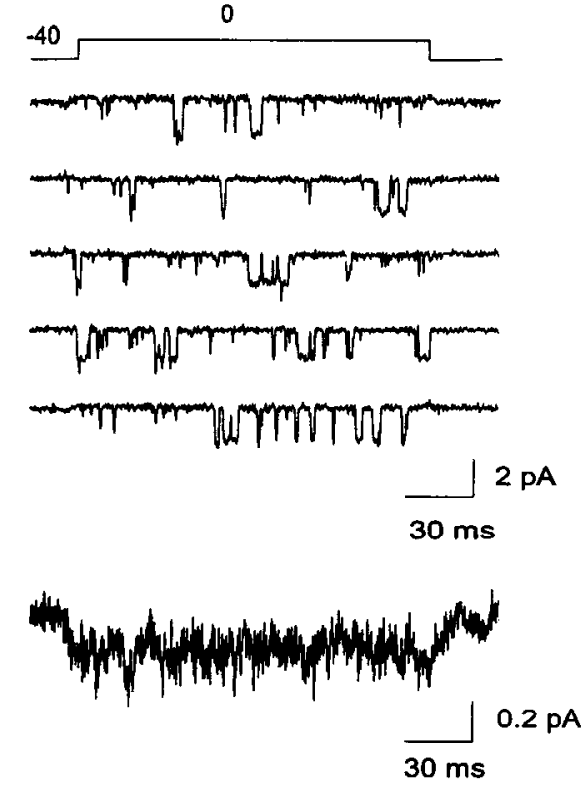

B

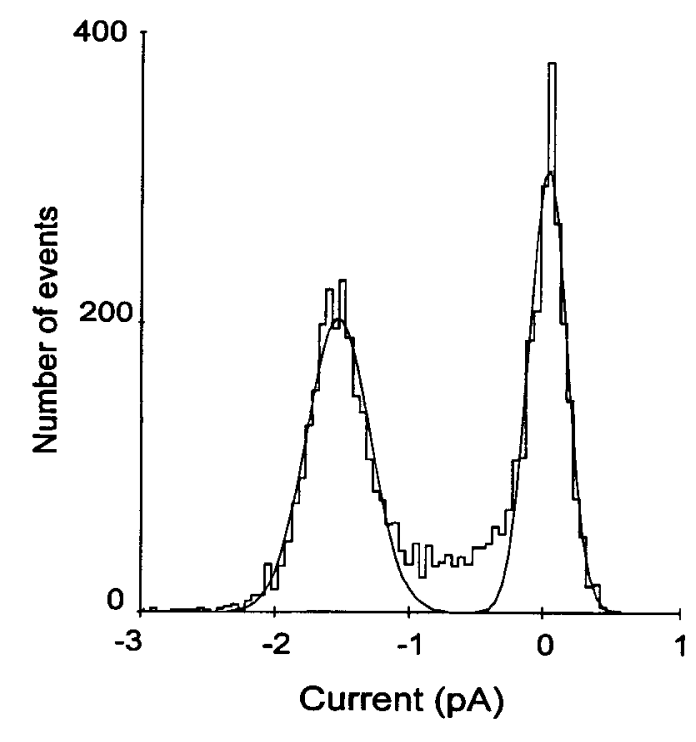

Figure 4. Single-channel activity of the $28 \mathrm{pS}$ channel. A, Sample records of the channel. The holding potential was $-40 \mathrm{mV}$, and the channel was activated by depolarizing steps to $0 \mathrm{mV}$ for $160 \mathrm{msec}$ every $4 \mathrm{sec}$. The bottom trace is the ensemble average of this channel at the same potentials derived from 27 swceps. $B$, Amplitude histogram of this channel at $0 \mathrm{mV}$ from a holding potential of $-40 \mathrm{mV}$. The distribution was fitted to the sum of two Gaussian functions shown in the figure. The open level is $-1.57 \mathrm{pA}$. The single-channel conductance of this channel between $-40 \mathrm{mV}$ and $20 \mathrm{mV}$ was $28.0 \mathrm{pS}$ (see Fig. $7 A$ ).

age dependency and steady-state inactivation $(n-3)$. Also, in two of three cells tested, the mean open time of these channels depended on holding potential (Fig. $3 B$ ). From holding potentials positive to $-60 \mathrm{mV}$, the openings were short and the open time distribution was well fitted to a single exponential function (time constant $=0.5 \mathrm{msec}$ ). In contrast, from negative holding potentials, long openings appeared and the open time distribution was no longer well fitted to a single exponential function (Figs. $2 C, 3 B$ ). This open time distribution was better fitted to double exponential functions with time constants of $0.54 \mathrm{msec}$ and $4.2 \mathrm{msec}$ (Fig. 2C). Such open time distributions indicate that these channels have two gating modes. From depolarized potentials, this channel opened for a brief duration with lowprobability openings. From more hyperpolarized potentials, the channel opened for longer duration with higher probability. It has been reported that $\mathrm{N}$-channels in sympathetic neurons have multiple modes of gating. In the high open-probability mode, the mean open time is longer than in other modes (Lipscombe et al., 1989; Plummer and Hess, 1991; Delcour et al., 1993). On the basis of single-channel conductance and kinetics, it is likely that the $14 \mathrm{pS}$ channel in HMs corresponds to the N-type channel seen in other neurons (Fox et al., 1987; Mogul and Fox, 1991).

\section{$28 \mathrm{pS}$ Calcium channels}

The largest calcium channel in HMs had a mean current amplitude of $-1.51 \pm 0.05 \mathrm{pA}(n=9)$ at $0 \mathrm{mV}$ (Fig. $4 B$ ) and a single-channel conductance averaging $28.3 \pm 0.3 \mathrm{pS}$ (range $=$ 26.5 to $29.7 \mathrm{pS}, n=13$ ) (see Fig. $7 A$ ). The ensemble average of this channel shows that the channel did not inactivate during depolarization (Fig. 4A). This channel did not show steady-state inactivation at depolarized holding potentials, such as $-40 \mathrm{mV}$. The kinetics and the weak dependency on holding potential of this channel are similar to those of L-channels in other neurons
(Fox et al., 1987). Accordingly, we found that this channel was sensitive to DHP analogs. A DHP agonist, Bay K $8644(2 \mu \mathrm{M})$, facilitated channel activity $(n=3)$ (Fig. $5 A, C)$. At the same time, Bay K 8644 shifted open time distributions of the channel toward long-duration openings $(n=3)$ (Fig. $5 B)$, characteristic of DHP agonist effects on L-type channels (Nowycky et al., 1985). Furthermore, a DHP antagonist, nifedipine $(2 \mu \mathrm{M})$, blocked channel activity $(n=4)$. Single-channel conductance, kinetics, voltage dependency, and sensitivity to DHP analogs indicate that this is an L-type channel (Fox et al., 1987).

\section{$20 \mathrm{pS}$ Calcium channels}

A fourth type of calcium channel had a $20 \mathrm{pS}$ single-channel conductance. Figure $6 A$ shows sample records of this channel and Figure $6 B$ shows an amplitude histogram of the channel. The amplitude distribution of the channel opening was skewed toward the baseline. As the channel openings were short and clustered (Fig. 6A), the skew may have resulted from filtering of short openings and closures. However, it is also possible that this channel showed subconductance openings, like the P-type channel in Purkinje cells (Usowicz et al., 1992). The mean current amplitude of this channel was $-1.03 \pm 0.03 \mathrm{pA}(n=7)$ at $0 \mathrm{mV}$ (Fig. $6 B$ ), with a mean slope conductance of $19.2 \pm$ $0.2 \mathrm{pS}$ (range $=18.5$ to $22.1 \mathrm{pS}, n-10$ ) (Fig. 74). Unlike the $14 \mathrm{pS}$ channel, the $20 \mathrm{pS}$ channel activated slowly and did not inactivate during depolarization (Fig. $6 A$ ). In addition, this channel was less sensitive to holding potential than the $14 \mathrm{pS}$ channel. Also, unlike the 14 and $28 \mathrm{pS}$ channels, the open time distribution at $0 \mathrm{mV}$ from a holding potential of $-40 \mathrm{mV}$ was well fitted to a single exponential function, with a time constant of $1.2 \mathrm{msec}$ (Fig. 6C). This time constant was not dependent on holding potential. For example, the time constant was similar to that at $0 \mathrm{mV}$ from a holding potential of $-60 \mathrm{mV}(1.13 \mathrm{msec})$. Similarly, the mean open time was $1.6 \mathrm{msec}$ from both holding 
A
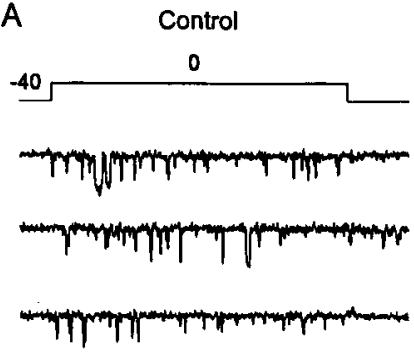

B
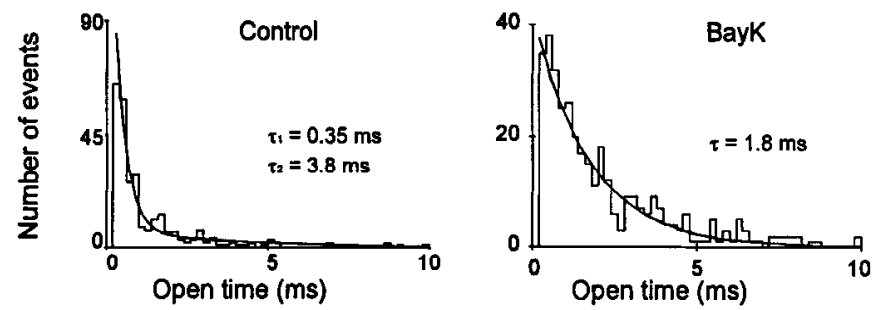

C

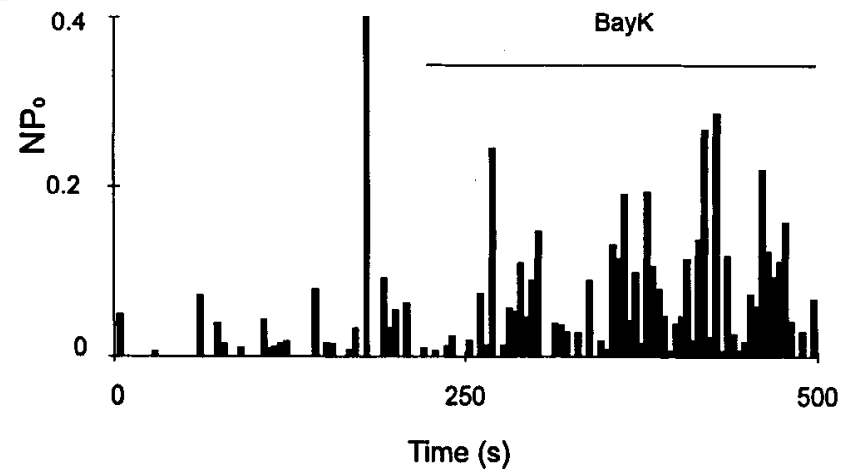

Figure 5. The effect of S(-)-Bay K $8644(2 \mu \mathrm{M})$ on a $28 \mathrm{pS}$ channel. $A$, Typical traces of channel activity bcforc and during bath application of Bay K 8644 . Holding potential was $-40 \mathrm{mV}$ and the calcium channel was activated by a depolarizing step to $0 \mathrm{mV}$ for $160 \mathrm{~ms}$ every $4 \mathrm{sec}$. $B$, Open time distribution of the channel during control and in the presence of Bay K 8644 are shown. In control, the open time distribution of the channel is fitted to the sum of two exponential functions with fractional contributions of 0.68 and 0.32 for $\tau_{1}$ and $\tau_{2}$, respectively. In the presence of Bay K 8644 the distribution is fitted to a single exponential function. Each time constant is shown in the figure. $C$, Channel activities $(\mathrm{NPo})$ in each sweep are plotted against recording time. Mean open probabilities are 0.023 and 0.067 before and during application of Bay K 8644, respectively.

potentials of $-40 \mathrm{mV}$ and $-60 \mathrm{mV}$. This channel was not a subclass of the L-type channel, as bath application of Bay $\mathrm{K}$ $8644(2 \mu \mathrm{M})$ was without effect $(n=3)$ when the channel was activated at $0 \mathrm{mV}$ from a holding potential of $-40 \mathrm{mV}$ (data not shown). This potential is positive to the threshold potential of the L-type channel. We chose this test potential because Bay K 8644 shifts the activation potential of L-type channels toward negative potentials (Hess et al., 1984; Fox et al., 1987). The single-chamnel properties of the $20 \mathrm{pS}$ channel were distinct from those of both the $14 \mathrm{pS}$ (N-type) and $28 \mathrm{pS}$ (L-type) channels, indicating that it corresponds to a different class of HVA channel. Given our previous finding that a major component of calcium currents in HMs is the P-type, we suggest that this channel is the P-type channel (Umemiya and Berger, 1994).

\section{Voltage dependency of HVA calcium channels}

Figure 7 shows unitary conductance and voltage-dependent activation of three types of HVA calcium channels. The activation thresholds for all three types of channels were positive to -20 $\mathrm{mV}$, indicating that they are subtypes of HVA calcium channels (Fig. $7 B$ ). The half activation potential of the $28 \mathrm{pS}$ channel (6.9 $\mathrm{mV})$ was intermediate between that of the $20 \mathrm{pS}$ channel $(-7.2$ $\mathrm{mV}$ ) and the $14 \mathrm{pS}$ channel (about $25.0 \mathrm{mV}$ ). The half-activation potential of the $14 \mathrm{pS}$ channel was the most positive of the HVA channels. For the $14 \mathrm{pS}$ chammel, the limit of recording resolution did not allow us to test for its maximum activation at potentials positive to $20 \mathrm{mV}$ (Fig. $7 B$ ). This positive half-activation potential may reflect the facilitation of the N-type channel by large depolarizations (Ikeda, 1991; Kuo and Bean, 1993). These differences in the voltage dependency of activation between the 14 and $20 \mathrm{pS}$ channels further support our hypothesis that these channels were distinct types.

\section{Discussion}

This study provides the first description of single-channel properties in a mammalian motoneuron. We found that HMs have at least four types of calcium channels based on their single-channel conductance. Mean single-channel conductances of each channel type were $7,14,20$, and $28 \mathrm{pS}$ using $110 \mathrm{~mm}$ barium as a charge carrier. Whole-cell calcium currents in HMs have been reported to have four components; a LVA calcium current and N-, P-, and L-type components of HVA currents (Viana et al., 1993; Umemiya and Berger, 1994). These four channel types may underlie the four components of whole-cell calcium currents, respectively.

The smallest channel $(7 \mathrm{pS})$ began to activate at more negative potentials than the other three types of channels and was sensitive to holding potential. Further, this channel inactivated during depolarized potentials. The inactivation time course of the ensemble average during depolarization was similar to that of whole-cell LVA calcium currents, suggesting that this type of channel is responsible for LVA calcium current (Umemiya and Berger, 1994). As these properties are similar to T-type channels in other neurons, it is likely that this is a T-type channel (Fox et al., 1987).

Three HVA calcium-channel subtypes in HMs were identified by their single-channel conductances. Single-channel conductances were similar to those reported for HVA channels in chromaffin cells, where $14 \mathrm{pS}$ (N-type), $19 \mathrm{pS}$, and $28 \mathrm{pS}$ (L-type) channels have been isolated (Artalejo et al., 1991, 1992). We concluded that the $28 \mathrm{pS}$ channel is an L-type channel, as the channel was sensitive to Bay K-8644 and nifedipine. DHPs were effective even applied outside of the patch, probably because they are lipid soluble and accumulate in the cell membrane ( $\mathrm{Ma}-$ son et al., 1991). The $28 \mathrm{pS}$ channel in HMs did not inactivate during depolarization and was insensitive to holding potential. These characteristics are similar to those of L-type channels in other neurons (Fox et al., 1987; Forti and Pietrobon, 1993). Whereas L-type channels were the most commonly observed channel type in our recordings from HM somata, the contribution of the L-type channel to whole-cell calcium current was small in HMs (Umemiya and Berger, 1994). Using an immunohistochemical method, Westenbroek et al. (1990) showed that the spatial distribution of calcium channels is uneven, and that 
A

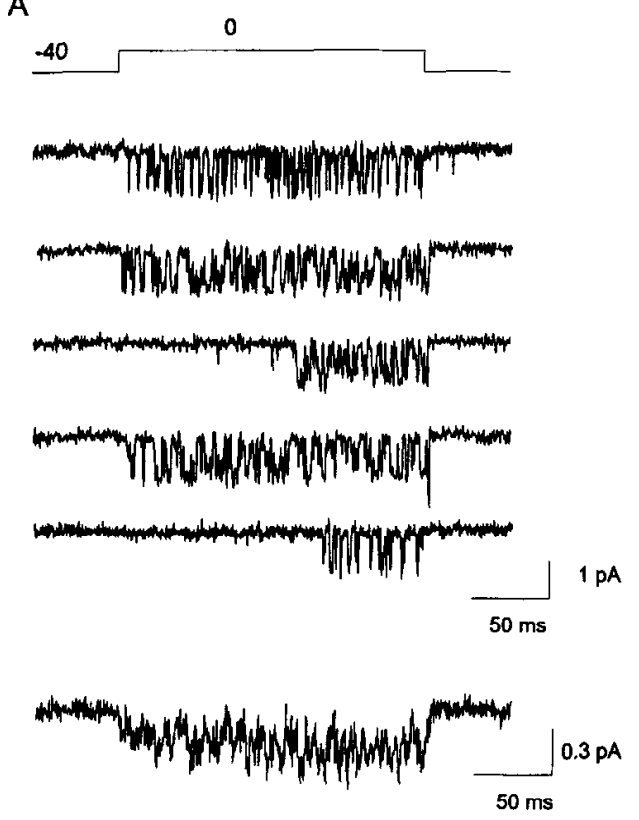

B
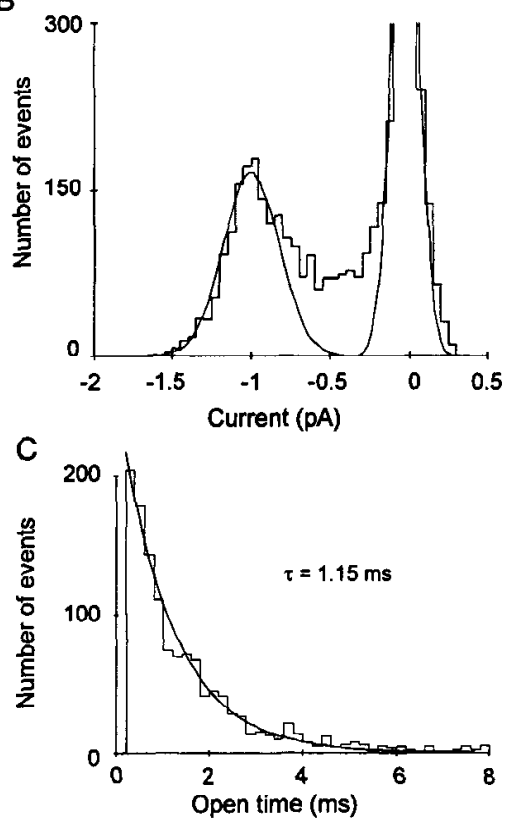

Figure 6. The $20 \mathrm{pS}$ channel. A, Channel activity at $0 \mathrm{mV}$ test potential from a holding potential of $-40 \mathrm{mV}$ is shown. The channel was activated with $200 \mathrm{msec}$ depolarizing steps to $0 \mathrm{mV}$ every $4 \mathrm{sec}$. The bottom traces is the ensemble average of channel activities obtained from 37 sweeps. B, All-points amplitude histogram at $0 \mathrm{mV}$ test potential from a holding potential of -40 $\mathrm{mV}$. The histogram was constructed from all points of the traces shown in A except for long closures in third and fifth traces. The smooth line shows a sum of two Gaussian functions that were calculated separately from the baseline distribution and the distribution of points more negative than $-0.75 \mathrm{pA}$. The open level is $-0.99 \mathrm{pA}$. The unitary conductance of this channel between -10 and $30 \mathrm{mV}$ is 20.6 pS (see Fig. 7A). The histogram peak of the baseline is truncated. $C$, Opentime distribution of this channcl at 0 $\mathrm{mV}$. Open-time distribution was fitted to a single exponential function and the time constant is shown.
L-type channels are located predominantly at somata. Comparing the minor contribution of L-type channels to the whole-cell calcium current and the relatively high frequency of single L-type channels, it is of interest whether or not this difference results from a differential spatial distribution of the channel (dendritic vs somatic).

In these experiments the identification of the 14 and $20 \mathrm{pS}$ calcium channels could not be undertaken using pharmacological methods. On the basis of kinetics, voltage dependency and single-channel conductance, the $14 \mathrm{pS}$ channels in HMs had similar characteristics to the $\mathrm{N}$-type channels in other neurons (Fox et al., 1987). The conductance of this channcl is similar to that of N-type channels in sympathetic neurons that do not express the P-type channel (Lipscombe et al., 1989; Mintz et al., 1992). Also, this conductance is similar to that of expressed class-B calcium channels that correspond to the $\mathrm{N}$-type channel
A

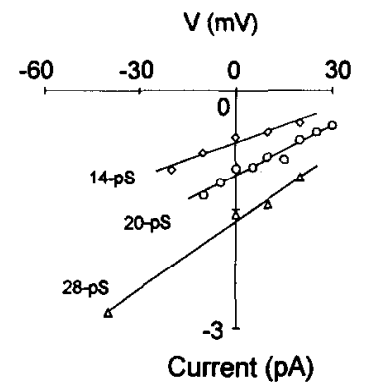

B

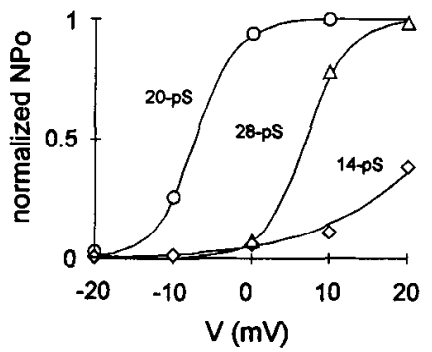

Figure 7. Voltage dependency of HVA calcium channels. A, Currentvoltage relationships of the HVA channels. The data were from the same patches as shown in Figures 2, 4, and 6. B, Voltage-dependent activation of the HVA calcium channels. Each point shows the average open probability that was derived from 64 sweeps and was normalized to the maximum open probabilities calculated from fitting to a single Boltzman function. The data are from different patches than those illustrated in $A$. The half-activation potentials and the slope factors are about $25.0 \mathrm{mV}$ and about $8.5 \mathrm{mV}$ for the $14 \mathrm{pS}$ channel, $-7.2 \mathrm{mV}$ and $2.7 \mathrm{mV}$ for the $20 \mathrm{pS}$ channel, and $6.7 \mathrm{mV}$ and $2.8 \mathrm{mV}$ for the $28 \mathrm{pS}$ channel, respectively,
(Fujita et al., 1993). Unlike its counterpart in chromaffin cells, but similar to the class-B calcium channel and N-type channels in peripheral and central neurons, this channel was sensitive to holding potential and inactivated during depolarization (Fox et al., 1987; Plummer et al., 1989; Artalejo et al., 1991; Mogul and Fox, 1991; Fujita et al., 1993). Also, similar to N-type channels in sensory and sympathetic neurons, the $14 \mathrm{pS}$ channel in HMs showed modal gating (Plummer and Hess, 1991; Delcour et al., 1993; Delcour and Tsien, 1993). Thus, it is likely that $14 \mathrm{pS}$ channels in HMs are N-type calcium channels. On the other hand, the $20 \mathrm{pS}$ channels in $\mathrm{HMs}$ did not inactivate during depolarizing potentials and were rather insensitive to holding potential. In sympathetic neurons, single-channel conductance of the N-type channel was $20 \mathrm{pS}$, but the N-type channel, in contrast to the $20 \mathrm{pS}$ channels in HMs, showed inactivation and was sensitive to the holding potential (Plummer et al., 1989; Rittenhouse and Hess, 1994). We did not test the effect of $\omega$-CgTx because $\omega$-CgTx is not effective in high-divalent cation concentrations (McCleskey et al., 1987) and because the frequency of recording this channel was low $(<7 \%)$, it would be inefficient to eliminate it by the antagonist pretreatment. However, given the different properties of 14 and $20 \mathrm{pS}$ channels, we conclude that these channels are distinct, with the $14 \mathrm{pS}$ channel being N-type.

The kinetics and voltage dependence of $20 \mathrm{pS}$ channel in HMs are similar to those of L- and the P-type channels in the CNS (Mogul and Fox, 1991; Regan et al., 1991; Usowicz et al., 1992; Forti and Pietrobon, 1993). In cerebellar granule cells, multiple subconductances of L-type channels were reported (Forti and Pietrobon, 1993). In HMs, we could find no evidence of subconductance openings of the L-type channel, such as direct transitions between different levels, and in only one of 23 patches did both the 20 and $28 \mathrm{pS}$ channel exist in the same patch. Also, the open time distribution of $20 \mathrm{pS}$ was different from that of $28 \mathrm{pS}$ channels. Finally, the lack of the effect of Bay K 8644 on the $20 \mathrm{pS}$ channel indicates that this channel does not represent a subconductance state of the L-type channcl, but is a unique channel type. 
P-type channels in Purkinje cells, where this type of channel is responsible for most of the HVA calcium current, have multiple subconductance levels (Usowicz et al., 1992). The largest conductance level in Purkinje cells is approximately $20 \mathrm{pS}$, the same as that of the $20 \mathrm{pS}$ channel in HMs. The skew in the amplitude distribution of the $20 \mathrm{pS}$ channel openings may indicate subconductance openings of the channel. The P-type channels in Purkinje cells are noninactivating during depolarization, similar to the $20 \mathrm{pS}$ channel in HMs (Usowicz et al., 1992). Also, noninactivating kinctics and wcak scnsitivity to holding potential are similar to that of $\omega$-Aga IVA-sensitive calcium currents in Purkinje cells and HMs (Regan, 1991; Umemiya and Berger, 1994). The $20 \mathrm{pS}$ channel activated at lower potentials than the $14 \mathrm{pS}$ channel and did not show clear modal gating. Aside from testing the DHP sensitivity, no other pharmacological characterization of this channel type was attempted. The specific peptide antagonist for P-type channels, $\omega$-Aga IVA, is not effective when applied from outside the recording pipette (Adams and Olivera, 1994). Since the frequency of recording this type of channel was low $(<14 \%)$, we did not try to eliminate it by the pretreatment with $\omega$-Aga IVA. Nevertheless, as the 20 pS channel has characteristics distinct from those of channels identified as T-, N-, and L-types, it is likely that this channel accounts for the P-type current that we previously identified in whole-cell recordings from HMs (Umemiya and Berger, 1994).

In the mammalian CNS, multiple types of the $\alpha$-subunit of voltage-dependent calcium channels have been cloned, and more than four types of calcium channels are expressed in CNS neurons (Snutch and Reiner, 1992; Sather et al., 1993). Our results show that there are at least four calcium channel types expressed in mammalian motoneurons and that each channel type has distinct single-channel properties.

\section{References}

Adams ME, Olivera BM (1994) Neurotoxins: overview of an emerging research technology. Trends Neurosci 17:151-155.

Artalejo CR, Mogul DJ, Perlman RL, Fox AP (1991) Three types of bovine chromaffin cell $\mathrm{Ca}^{2+}$ channels: facilitation increases the opening probability of a 27 pS channel. J Physiol (Lond) 444:213 240.

Artalejo CR, Perlman RL, Fox AP (1992) Omega-conotoxin GVIA blocks a $\mathrm{Ca}^{2+}$ current in bovine chromaffin cells that is not of the "classic" N type. Neuron 8:85-95.

Bean BP (1989) Classes of calcium channels in vertebrate cells. Annu Rev Physiol 51:367-384.

Delcour AH, Tsien RW (1993) Altered prevalence of gating modes in neurotransmitter inhibition of $\mathrm{N}$-type calcium channels. Science 259: 980984

Delcour AH, Lipscombe D, Tsien RW (1993) Multiple modes of $\mathrm{N}$-type calcium channel activity distinguished by differences in gating kinetics. J Neurosci 13:181-194.

Edwards FA, Konnerth A, Sakmann B, Takahashi T (1989) A thin slice preparation for patch clamp recordings from neurones of the mammalian central nervous system. Pflugers Arch 414(5):600-612.

Forti L, Pietrobon D (1993) Functional diversity of L-type calcium channels in rat cerebellar neurons. Neuron 10:437-450.

Fox AP, Nowycky MC, Tsien RW (1987) Single-channel recordings of three types of calcium channels in chick sensory neurones. J Physiol (Lond) 394:173-200.

Fujita Y, Mynlieff M, Dirksen RT, Kim M-S, Niidome T, Nakai J, Friedrich T, Iwabe N, Miyata T, Furuichi T, Furutama D, Mikoshiba K, Mori Y, Beam KG (1993) Primary structure and functional expres- sion of the omega-conotoxin-sensitive $\mathrm{N}$-type calcium channel from rabbit brain. Neuron 10:585-598.

Hess P, Lansman JB, Tsien RW (1984) Different modes of Ca channel gating behaviour favoured by dihydropyridine $\mathrm{Ca}$ agonists and antagonists. Nature 311:538-544.

Ikeda SR (1991) Double-pulse calcium channel current facilitation in adult rat sympathetic neurones. J Physiol (Lond) 439:181-214.

Kuo CC, Bean BP (1993) G-protein modulation of ion permeation through N-type calcium channels. Nature 365:258-262.

Lipscombe D, Kongsamut S, Tsien RW (1989) Alpha-adrenergic inhibition of sympathetic neurotransmitter release mediated by modulation of N-type calcium-channel gating. Nature 340:639-642.

Llinas R, Sugimori M, Hillman DE, Cherksey B (1992) Distribution and functional significance of the P-type, voltage-dependent $\mathrm{Ca}^{2+}$ channels in the mammalian central nervous system. Trends Neurosci 15:351-355.

Mason RP, Rhodes DG, Herbette LG (1991) Reevaluating equilibrium and kinetic binding parameters for lipophilic drugs based on a structural model for drug interaction with biological membranes. J Med Chem 34:869-877.

McCleskey EW, Fox AP, Feldman DH, Cruz LJ, Olivera BM, Tsien RW, Yoshikami D (1987) Omega-conotoxin: direct and persistent blockade of specific types of calcium channels in neurons but not muscle. Proc Natl Acad Sci USA 84:4327-4331.

Mintz IM, Adams ME, Bean BP (1992) P-Type calcium channels in rat central and peripheral neurons. Neuron 9:85-95.

Mogul DJ, Fox AP (1991) Evidence for multiple types of $\mathrm{Ca}^{2+}$ channels in acutely isolated hippocampal CA3 neurones of the guineapig. J Physiol (Lond) 433:259-281.

Nowycky MC, Fox AP, Tsien RW (1985) Long-opening mode of gating of neuronal calcium channels and its promotion by the dihydropyridine calcium agonist Bay K 8644. Proc Natl Acad Sci USA 82: $2178-2182$.

O'Dell TJ, Alger BE (1991) Single calcium channels in rat and guineapig hippocampal neurons. J Physiol (Lond) 436:739-767.

Plummer MR, Hess P (1991) Reversible uncoupling of inactivation in N-type calcium channels. Nature 351:657-659.

Plummer MR, Logothetis DE, Hess P (1989) Elementary properties and pharmacological sensitivities of calcium channels in mammalian peripheral neurons. Neuron 2:1453-1463.

Regan LJ (1991) Voltage-dependent calcium currents in Purkinje cells from rat cerebellar vermis. J Neurosci 11:2259-2269.

Regan LJ, Sah DW, Bean BP (1991) $\mathrm{Ca}^{2+}$ channels in rat central and peripheral neurons: high-threshold current resistant to dihydropyridine blockers and omega-conotoxin. Neuron 6:269-280.

Rittenhouse AR, Hess P (1994) Microscopic heterogeneity in unitary $\mathrm{N}$-type calcium currents in rat sympathetic neurons. J Physiol (Lond) 474:87-99.

Sather WA, Tanabe T, Zhang J-F, Mori Y, Adams ME, Tsien RW (1993) Distinctive biophysical and pharmacological properties of class A (BI) calcium channel $a_{1}$ subunits. Neuron 11:291-303.

Snutch TP, Reiner PB (1992) $\mathrm{Ca}^{2+}$ channels: diversity of form and function. Curr Opin Neurobiol 2:247-253.

Takahashi $\mathrm{T}$ (1992) The minimal inhibitory synaptic currents evoked in meonatal rat motoneurones. J Physiol (Lond) 450:593-611.

Tsien RW, Ellinor PT, Horne WA (1991) Molecular diversity of voltage-dependent $\mathrm{Ca}^{2+}$ channels. Trends Pharmacol Sci 12:349-354.

Umemiya $M$ and Berger AJ (1994) Properties and function of lowand high-voltage-activated $\mathrm{Ca}^{2+}$ channels in hypoglossal motoneurons. J Neurosci 14:5652-5660.

Usowicz MM, Sugimori M, Cherksey B, Llinás R (1992) P-type calcium channels in the somata and dendrites of adult cerebellar Purkinjc cells. Ncuron 9:1185-1199.

Viana F, Bayliss DA, Berger AJ (1993) Calcium conductances and their role in the firing behavior of neonatal rat hypoglossal motoneurons. J Neurophysiol 69:2137-2149.

Westenbroek RE, Ahlijanian MK, Catterall WA (1990) Clustering of L-type $\mathrm{Ca}^{2+}$ channels at the base of major dendrites in hippocampal pyramidal neurons. Nature 347:281-284. 